\title{
Is PCR better than culture in TB diagnosis: myth or reality?
}

\author{
Ruqaiyah Johar*, Kiran Chawla, Chiranjay Mukhopadhyay \\ From 2nd International Science Symposium on HIV and Infectious Diseases (HIV SCIENCE 2014) \\ Chennai, India. 30 January - 1 February 2014
}

\section{Background}

Polymerase chain reaction (PCR) is emerging as a new diagnostic tool for tubercular infections. Studies indicate variable results in relation to its efficacy making it as an investigation which is operator dependant. It still remains a dilemma to choose between PCR and culture as the most dependant and reliable diagnostic test. The purpose of our study was to determine the efficacy of PCR in diagnosis of pulmonary and extra-pulmonary tuberculosis and its comparison with conventional culture.

\section{Methods}

In this observational study, 50 pulmonary and 50 extrapulmonary specimens from suspected tuberculosis patients were included. All samples after initial processing were subjected to microscopy, conventional culture and PCR.

\section{Results}

For pulmonary specimens, positivity of smear, culture and PCR were $56 \%, 72 \%$ and $74 \%$, respectively. Sensitivity and specificity of PCR was found to be $89 \%$ and $71 \%$ respectively. For extra-pulmonary specimens, positivity of smear, culture and PCR were $36 \%, 58 \%$ and $78 \%$, respectively. Sensitivity and specificity of PCR was found to be $83 \%$ and $29 \%$ respectively (with culture as gold standard) whereas it was $92 \%$ and $67 \%$, respectively (with clinical diagnosis as gold standard). PCR facilitated additional detection of $4 \%$ and $20 \%$ pulmonary and extra-pulmonary TB cases respectively than by conventional culture. Results of PCR were obtained in 6-8 hours as compared to 6-8 weeks by conventional culture.

*Correspondence: dr.rukki@gmail.com

Department of Microbiology, Kasturba Medical College, Manipal University, Manipal, India

\section{Conclusion}

The study highlights PCR as a better diagnostic tool in detection of tuberculosis. Early results of PCR help in early institution of anti tubercular treatment and thus controlling the spread of disease.

Published: 27 May 2014

doi:10.1186/1471-2334-14-S3-P46

Cite this article as: Johar et al.: Is PCR better than culture in TB

diagnosis: myth or reality? BMC Infectious Diseases 2014 14(Suppl 3):P46.
Submit your next manuscript to BioMed Central and take full advantage of:

- Convenient online submission

- Thorough peer review

- No space constraints or color figure charges

- Immediate publication on acceptance

- Inclusion in PubMed, CAS, Scopus and Google Scholar

- Research which is freely available for redistribution

Submit your manuscript at www.biomedcentral.com/submit
() Biomed Central 